\title{
Utilization of refractory cellulosic carbon derived from Spartina alterniflora by the ribbed mussel Geukensia demissa
}

\author{
Daniel A. Kreeger ${ }^{1 *}$, Christopher J. Langdon ${ }^{2}$, Roger I. E. Newell ${ }^{3}$ \\ ${ }^{1}$ College of Marine Studies, University of Delaware, 700 Pilottown Road, Lewes, Delaware 19971, USA \\ ${ }^{2}$ Hatfield Marine Science Center, Oregon State University, Newport, Oregon 97365, USA \\ ${ }^{3}$ Center for Environmental and Estuarine Studies, Horn Point Laboratories, University of Maryland, PO Box 775, Cambridge, \\ Maryland 21613, USA
}

\begin{abstract}
The ability of the ribbed mussel Geukensia demissa (Dillwyn) to ingest and absorb refractory lignocellulosic carbon was evaluated using ${ }^{14} \mathrm{C}$-radiotracer techniques. Mussels were maintained in a simulated tidal cycle of $6 \mathrm{~h}$ submergence and $6 \mathrm{~h}$ exposure and were fed on $\left[{ }^{14} \mathrm{C}\right]$ lignocellulose during the first submergence period. The mean $\left( \pm \mathrm{SD}\right.$ ) absorption efficiency for ${ }^{14} \mathrm{C}$ was $13.3 \pm$ $2.5 \%$ in an experiment performed in January 1985 , and $14.2 \pm 1.6 \%$ in a second experiment conducted in March 1985. Approximately $29 \%$ of absorbed ${ }^{14} \mathrm{C}$ was respired and $31 \%$ incorporated into the protein/lipid fraction of the mussel. Mean ( \pm SD) cellulose concentration in seston samples collected in the summer from a small creek draining a Delaware salt marsh was $66 \pm 28 \mu \mathrm{gl}^{-1}$. It was estimated that adult ribbed mussels in this marsh could obtain $15 \%$ of their total carbon requirements in the summer by utilization of refractory cellulosic material.
\end{abstract}

\section{INTRODUCTION}

The ribbed mussel Geukensia demissa (Dillwyn) has been reported to be the dominant animal in salt marshes of the eastern United States (Kuenzler 1961a, Jordan \& Valiela 1982). Filtration and biodeposition by G. demissa can be important agents in the cycling of energy (Kuenzler 1961a), phosphorus (Kuenzler 1961b), and nitrogen (Jordan \& Valiela 1982) in the marsh. Despite the obvious importance of $G$. demissa in salt marsh ecosystems (Jordan \& Valiela 1982), few studies have examined the mussel's ability to utilize refractory carbon from the dominant vascular plant. Spartina alterniflora (Teal 1962)

Salt marshes are detritus-based systems and most of the detrital material is derived from Spartina alterniflora (Teal 1962, Odum \& de la Cruz 1967, Marinucci 1982, Valiela et al. 1985). Approximately 70 to $82 \%$ of the dry weight of live $S$. alterniflora is carbohydrate (Squiers \& Good 1974, Smith et al. 1979), of which $90 \%$ is structural lignocellulose (McIntire \& Dunstan 1976,

\footnotetext{
- Present address: Hatfield Marine Science Center, Oregon
} State University, Newport, Oregon 97365, USA.
Maccubbin \& Hodson 1980). Very little S. alterniflora is grazed by herbivores prior to senescence (Pomeroy \& Wiegert 1981). Following senescence, non-structural components are rapidly removed from $S$. alterniflora by bacteria and fungi (Benner et al. 1984) or by natural leaching processes (Haines \& Hanson 1979, Wilson et al. 1986). Approximately $20 \%$ of post-senescent plant material may be exported from the marsh during unusually high tides (Pickral \& Odum 1976) or by ice rafting (Heinle \& Flemer 1976). However, most of the structural lignocellulose remains in the marsh and slowly decomposes in situ (Maccubbin \& Hodson 1980, Valiela et al. 1985).

Filter-feeding bivalves typically assimilate phytoplankton with an efficiency greater than $75 \%$ (Winter 1978, Bayne \& Newell 1983). In contrast, bivalves apparently are unable to efficiently assimilate refractory compounds such as lignocellulose. Growth studies indicate that salt marsh grass detritus is a poor food for Argopecten irradians (Kirby-Smith 1976), Mytilus edulis (Williams 1981), and Crassostrea virginica (Pennock 1981). Stuart et al. (1982) reported that the mussel Aulacomya ater assimilated kelp detritus with an efficiency of $50 \%$; however, detritus from kelp is 
more easily degraded than detritus derived from salt marsh vascular plants (Findlay \& Tenore 1982). Newell \& Langdon (1986) and Crosby (1987) found that the oyster Crassostrea virginica has a digestion efficiency of less than $3 \%$ for $\left[{ }^{14} \mathrm{C}\right]$ lignocellulose prepared from Spartina alterniflora.

In contrast, stable isotope studies (Haines \& Montague 1979, Hughes \& Sherr 1983) indicate that material derived from Spartina alterniflora may be important in the nutrition of intertidal fauna such as Geukensia demissa. Peterson et al. (1985) measured the stable isotope ratios of carbon, nitrogen, and sulfur in tissues of $G$. demissa collected from the Great Sippewissett Marsh. Mussels from the marsh interior had an isotopic signature indicating that $80 \%$ of the assimilated diet was derived from $S$. alterniflora whereas the diet of mussels collected from seaward creeks was estimated to consist of $70 \%$ phytoplankton.

In this study, the ability of Geukensia demissa to directly utilize lignocellulosic carbon prepared from Spartina alterniflora was quantified using ${ }^{14} \mathrm{C}$ tracer techniques, under conditions simulating their natural, intertidal habitat.

\section{METHODS}

Production of $\left[{ }^{14} \mathrm{C}\right]$ lignocellulose from Spartina alterniflora. Dormant short-form $S$. alterniflora plants with associated soil were collected from the Canary Creek marsh, Delaware, USA $\left(38^{\circ} 47^{\prime} \mathrm{N}, 75^{\circ} 10^{\prime} \mathrm{W}\right)$ in March 1985. They were transplanted into $4 \mathrm{l}$ plastic pots and held at $5{ }^{\circ} \mathrm{C}$ until use. All above-ground biomass was removed. In June 1985, 4 pots of plants were labeled with ${ }^{14} \mathrm{CO}_{2}$, according to the methods described by Newell \& Langdon (1986). The ${ }^{14} \mathrm{C}$-labeled plants were harvested, dried and the lipid and protein fractions were chemically removed. The residue was then treated with hot acid and hot alkali to remove non-lignocellulosic material (Newell \& Langdon 1986).

Newell \& Langdon (1986) produced a refractory material with $88 \%$ of the ${ }^{14} \mathrm{C}$ label distributed in the cellulose fraction, $8 \%$ in the lignin fraction and $4 \%$ in the starch fraction. Starch content was reduced further in this study by incubating the extracted plant material with $\alpha$-amylase for $24 \mathrm{~h}$. After incubation, the extracted material was separated from the digest by centrifugation $(1400 \times \mathrm{g}, 10 \mathrm{~min})$ and washed twice with distilled water. The product was ground, sieved with a $20 \mu \mathrm{m}$ sieve and lyophilized.

Triplicate subsamples of the ${ }^{14} \mathrm{C}$-labeled material were weighed and suspended homogeneously in a gel formed with $10 \mathrm{ml}$ Aquasol (New England Nuclear Research Products) and $3 \mathrm{ml}$ distilled water, and the ${ }^{14} \mathrm{C}$-specific activity determined by scintillation count- ing. The distribution of ${ }^{14} \mathrm{C}$ among cellulose, lignin, starch, lipid and protein fractions was determined according to the methods described by Newell \& Langdon (1986)

Feeding experiments with $\left[{ }^{14} \mathrm{C}\right]$ lignocellulose. Collection and acclimation of Geukensia demissa. Adult ribbed mussels were collected for experiments in January (mean \pm SD dry tissue weight [DTW] $=0.36 \pm$ $0.10 \mathrm{~g}$ ) and March (mean \pm SD DTW $=0.28 \pm 0.03 \mathrm{~g}$ ) from the Canary Creek marsh. The mussels were collected from a marsh elevation with an approximate tidal periodicity of $6 \mathrm{~h}$ submergence and $6 \mathrm{~h}$ exposure. Mussels were maintained in the laboratory under submergence/exposure conditions which were in synchrony with natural tidal periodicity during both acclimation and experimentation in order to avoid disturbing their natural digestive rhythm (Gillmor 1982, Morton 1983). Mussels were acclimated to laboratory temperature $\left(21^{\circ} \mathrm{C}\right)$ for 2 to $3 \mathrm{wk}$ before experimentation. Unfiltered marsh water was added to the culture system to provide the mussels with a diet of natural seston.

Experimental design. Water was collected from Canary Creek prior to each experiment and warmed to $21^{\circ} \mathrm{C}$. Prefiltered (38 $\mu \mathrm{m}$ mesh) marsh water was continuously delivered at a mean $( \pm \mathrm{SD}$ ) flow rate of 0.43 ( \pm 0.11 ) $\mathrm{l} \mathrm{h}^{-1}$ to mussels held individually in $1 \mathrm{l}$ beakers. Water drained from each beaker through an overflow tube positioned at a level which maintained $700 \mathrm{ml}$ of water in each beaker. The beakers were gently mixed with magnetic stirrers to prevent particle settlement. Each beaker contained either one live Geukensia demissa or a 'control mussel' consisting of a pair of empty mussel shells glued together. Each mussel or control was positioned on a plastic Petri dish suspended above the bottom of the beaker.

The experimental mussels were subjected to a $6 \mathrm{~h}$ submergence: $6 \mathrm{~h}$ exposure cycle in the 2 feeding experiments as shown in Fig. 1 . The $\left[{ }^{14} \mathrm{C}\right]$ lignocellulose was suspended homogeneously in marsh water and delivered to the mussels during the first $6 \mathrm{~h}$ period of submergence only. A total of approximately $1.35 \mu \mathrm{Ci}$ (9.64 mg cellulosic material) was delivered to each chamber over this $6 \mathrm{~h}$ feeding period.

Clearance of $I^{14}$ Cllignocellulose. Water samples $(20 \mathrm{ml})$ were collected in rapid succession from the inflow, outflow, and water immediately above each mussel every $2 \mathrm{~h}$. during the first submergence period. The time required to collect each sample was recorded and used to calculate flow rates of seawater through the experimental chambers. Samples were preserved with $1 \% \mathrm{w} / \mathrm{v}$ (final concentration) formalin and were stored at $5^{\circ} \mathrm{C}$. The instantaneous filtration rates $(F R)$ of mussels fed on the $\left[{ }^{14} \mathrm{C}\right.$ llignocellulose particles were calculated using a formula adapted from Hildreth \& Crisp (1976). 
Fig. 1. Protocol for submergence and exposure of Geukensia demissa prior to (dashed line) and during (solid line) Expts 1 and 2

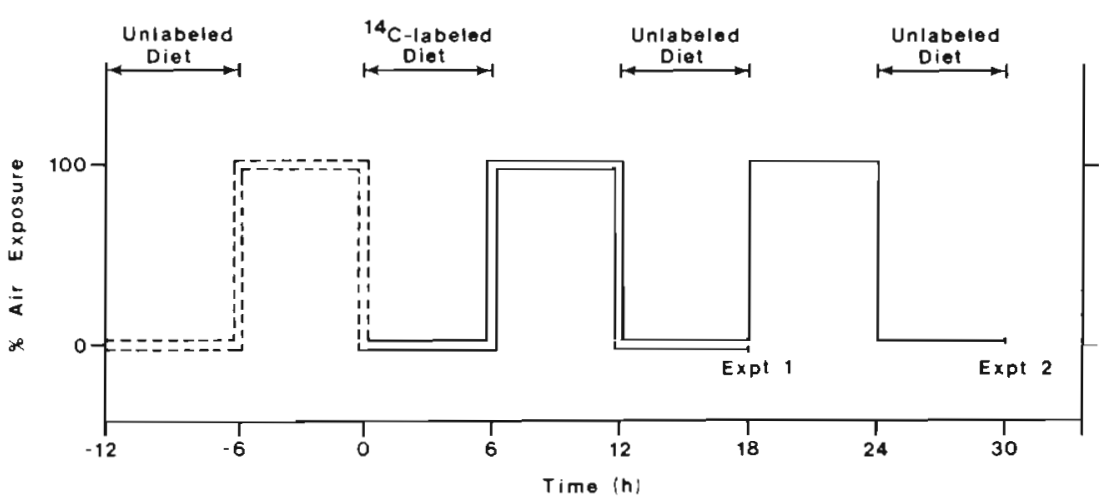

$\mathrm{FR}(\mathrm{ml} \mathrm{min}-1)=\frac{\mathrm{I}-\mathrm{O}}{\mathrm{M}} \times$ flow rate $\left(\mathrm{ml} \mathrm{min}^{-1}\right)$

where $\mathrm{I}, \mathrm{O}$ and $\mathrm{M}$ refer to the respective radioactivities (dpm $\mathrm{ml}^{-1}$ ) of inflow, outflow, and chamber samples. This formula corrects for refiltration of water by the mussels in the experimental chambers (Hildreth \& Crisp 1976). Filtration rates were corrected for particle settlement by subtraction of settlement rates measured in control beakers. Instantaneous mussel clearance rates ( $\mathrm{dpm} \mathrm{min}^{-1}$ ) were determined every $2 \mathrm{~h}$ by multiplying filtration rates $\left(\mathrm{ml} \mathrm{min}^{-1}\right)$ by the respective specific radioactivities of the water in the chambers $\left(\mathrm{dpm} \mathrm{ml}^{-1}\right)$. The total amount of $\left[{ }^{14} \mathrm{C}\right]$ lignocellulose cleared per mussel during the first period of submergence was estimated by integration for each $2 \mathrm{~h}$ period between samples.

Biodeposition of ${ }^{14} \mathrm{C}$. Feces and pseudofeces were collected at hourly intervals during each experiment. Pseudofeces were distinguished from feces by their production from the posterior end of the bivalve, whereas feces were produced along the dorso-posterior margin. Pseudofeces only contained ${ }^{14} \mathrm{C}$ when $\left[{ }^{14} \mathrm{C}\right]$ lignocellulose was present in the surrounding water; therefore, pseudofeces were only collected during the first submergence period. Biodeposits were collected, diluted to $20 \mathrm{ml}$ with $1 \% \mathrm{w} / \mathrm{v}$ (final concentration) formalin, and sonicated to disperse clumps. A subsample of $3 \mathrm{ml}$ was added to $10 \mathrm{ml}$ Aquasol for determination of ${ }^{14} \mathrm{C}$-activity. Hourly measurements of ${ }^{14} \mathrm{C}$ in feces and pseudofeces were summed to calculate total production of ${ }^{14} \mathrm{C}$ in both types of biodeposits. The depuration period after feeding mussels ${ }^{14} \mathrm{C}$-material (12 to $24 \mathrm{~h}$ ) was sufficient for all undigested ${ }^{14} \mathrm{C}$ to be voided from the gut of Geukensia demissa (Kreeger 1986).

Respiration of ${ }^{14} \mathrm{C}$. Respiration of ${ }^{14} \mathrm{C}$ by each ribbed mussel was measured for each $6 \mathrm{~h}$ time period. During periods of submergence, vials containing $600 \mu \mathrm{l}$ of $38 \%$ $\mathrm{w} / \mathrm{V} \mathrm{KOH}$ were suspended above the water surface of the beakers to absorb ${ }^{14} \mathrm{CO}_{2}$ and the beakers were sealed with 'Parafilm'. However, no ${ }^{14} \mathrm{CO}_{2}$ was meas- ured in the air above the water surface of the beakers, probably because the seawater was alkaline, at $\mathrm{pH} 7.9$, and $\mathrm{CO}_{2}$ solubility was high. Respired ${ }^{14} \mathrm{CO}_{2}$ from submerged mussels was detected in the effluent water of the beakers. Effluent from each beaker was collected in 21 stoppered flasks containing $1 \% \mathrm{w} / \mathrm{v}$ (final concentration) formalin. At the end of each submergence period, the volume of water collected in each $2 \mathrm{l}$ flask was recorded, and a $100 \mathrm{ml}$ sub-sample was transferred to a $150 \mathrm{ml}$ flask. A $5 \mathrm{ml}$ glass test tube containing 600 ul $38 \% \mathrm{w} / \mathrm{v} \mathrm{KOH}$ was then added to each flask. Each $150 \mathrm{ml}$ water sample was acidified to $\mathrm{pH}<3.0$ with $1 \mathrm{ml} 75 \% \mathrm{v} / \mathrm{v} \mathrm{H}_{2} \mathrm{SO}_{4}$ to liberate $\mathrm{CO}_{2}$ which was then trapped by $\mathrm{KOH}$ in the test tubes. After $1 \mathrm{wk}, 200 \mu \mathrm{l}$ of $\mathrm{KOH}$ from each test tube was added to $10 \mathrm{ml}$ Aquasol together with $1.8 \mathrm{ml}$ methanol (to solubilize $\mathrm{KOH}$ ) for ${ }^{14} \mathrm{C}$-counting. Radioactivity measurements of samples were corrected for $\mathrm{CO}_{2}$ trapping efficiency, measured as $79.9 \%$ with $\left[{ }^{14} \mathrm{C}\right] \mathrm{NaHCO}_{3}$ standards. The average total ${ }^{14} \mathrm{CO}_{2}$ activity of marsh water collected from control chambers (microbial respiration) was subtracted from the total ${ }^{14} \mathrm{CO}_{2}$ activity of each experimental beaker to estimate ${ }^{14} \mathrm{C}$-respiration by each submerged mussel.

Following each $6 \mathrm{~h}$ period of submergence, live Geukensia demissa and controls were gently rinsed with fresh marsh water and individually placed in empty stoppered 21 flasks for a $6 \mathrm{~h}$ period of exposure. A humid atmosphere was created in each flask by addition of $1 \mathrm{ml}$ distilled water. A vial containing $600 \mu \mathrm{l}$ $38 \% \mathrm{w} / \mathrm{v} \mathrm{KOH}$ was suspended in each flask to trap respired ${ }^{14} \mathrm{CO}_{2}$ during exposure. After exposure, mussels and controls were gently returned to clean beakers and a $200 \mu \mathrm{l}$ aliquot of $\mathrm{KOH}$ from each $\mathrm{CO}_{2}$ trap was added to $10 \mathrm{ml}$ Aquasol and $1.8 \mathrm{ml}$ methanol for ${ }^{14} \mathrm{C}$-counting. The radioactivity of each sample was corrected for the trapping efficiency of this technique, measured as $65.9 \%$ with $\left[{ }^{14} \mathrm{C}\right] \mathrm{NaHCO}_{3}$ standards. The mean total ${ }^{14} \mathrm{CO}_{2}$ activity of control flasks (microbial respiration) was subtracted from the total ${ }^{14} \mathrm{CO}_{2}$ activity of each flask holding a live mussel to determine the mussel's aerial production of ${ }^{14} \mathrm{CO}_{2}$. Total respiration 
by each mussel over the experimental period was the sum of ${ }^{14} \mathrm{CO}_{2}$ respired during the periods of submergence and exposure.

Body absorption and incorporation of ${ }^{14} \mathrm{C}$. Dry tissue weights were determined for each mussel by lyophilizing (VirTis model 10-010) the body tissue in pre-weighed vials. Three control mussels not used in the feeding experiments were treated similarly. Each tissue sample was ground in a ball mill (Crescent 'WigL-Bug') and suspended in $10 \mathrm{ml}$ sterile seawater. The ${ }^{14} \mathrm{C}$-specific activity of each tissue sample was determined.

Undigested $\left[{ }^{14} \mathrm{C}\right]$ lignocellulose that may have remained in the mussels was separated from digested and absorbed ${ }^{14} \mathrm{C}$ by alkali and acid extraction (Newell \& Langdon 1986). Subsamples of $2 \mathrm{ml}$ mussel tissue suspension were each added to $8 \mathrm{ml} 0.9 \% \mathrm{v} / \mathrm{v} \mathrm{H}_{2} \mathrm{SO}_{4}$, mixed for $30 \mathrm{~s}$, heated at $95^{\circ} \mathrm{C}$ for $30 \mathrm{~min}$, centrifuged at $1400 \times \mathrm{g}$ for $10 \mathrm{~min}$, and the supernatant removed. The pellet of each sample was washed with $10 \mathrm{ml}$ distilled water, resuspended in $10 \mathrm{ml} 12.5 \% \mathrm{w} / \mathrm{v}$ $\mathrm{NaOH}$, mixed for $30 \mathrm{~s}$, heated at $95^{\circ} \mathrm{C}$ for $30 \mathrm{~min}$, and centrifuged at $1400 \times \mathrm{g}$ for $10 \mathrm{~min}$. Each pellet was again washed with $10 \mathrm{ml}$ distilled water and resuspended in a gel of $10 \mathrm{ml}$ Aquasol and $3 \mathrm{ml}$ distilled water for determination of ${ }^{14} \mathrm{C}$-activity. Pellet ${ }^{14} \mathrm{C}$ represented $\left[{ }^{14} \mathrm{C}\right]$ lignocellulose not digested by the mussel. The solubilized ${ }^{14} \mathrm{C}$ tissue fraction of each sample was corrected for solubilization of $\left[{ }^{14} \mathrm{C}\right.$ lignocellulose by the acid/alkalj extraction, which was found to be $31 \%$, based on results from $\left[{ }^{14} \mathrm{C}\right]$ lignocellulose controls which were similarly treated with acid and alkali.

The proportions of incorporated ${ }^{14} \mathrm{C}$ present in the lipid and protein fractions of Geukensia demissa were determined in the second (March) feeding experiment. Lipid was extracted with the chloroform/methanol method described by Holland \& Gabbott (1971) and the percent of tissue ${ }^{14} \mathrm{C}$ in the form of $\left[{ }^{14} \mathrm{C}\right.$ ]lipid calculated. Protein was extracted with a technique modified from Holland \& Gabbott (1971) where each tissue sample was heated at $95^{\circ} \mathrm{C}$ for $30 \mathrm{~min}$ in a solution of $5 \%$ trichloroacetic acid (TCA). The ${ }^{14} \mathrm{C}$-specific activity of each pellet was expressed as a percent of the total incorporated ${ }^{14} \mathrm{C}$ to calculate the proportion of tissue ${ }^{14} \mathrm{C}$ present as $\left[{ }^{14} \mathrm{C}\right]$ protein.

Calculations. Ingestion (I) of the ${ }^{14} \mathrm{C}$-labeled diet by Geukensia demissa was calculated indirectly by 2 methods:

$$
\begin{aligned}
\text { and } & I_{1}=(C-P) \\
I_{2} & =\left(F+R+B_{a}+B_{n}\right)
\end{aligned}
$$

where $\mathrm{C}=$ clearance; $\mathrm{P}=$ pseudofecal deposition; $\mathrm{F}=$ fecal deposition; $\mathrm{R}=$ respiration; $\mathrm{B}_{\mathrm{a}}=$ body absorption; $B_{n}=$ non-absorbed gut material. Eq. (3) is valid if non-fecal excretion of ${ }^{14} \mathrm{C}$ is insignificant. Absorbed energy lost as excreted amino acids was considered negligible in unstressed Geukensia demissa (Bayne 1976) and was not measured in this study. Total absorption $(\mathrm{A})$ of ${ }^{14} \mathrm{C}$ was determined by addition of respired ${ }^{14} \mathrm{C}$ and absorbed body burden of ${ }^{14} \mathrm{C}$ :

$$
\mathrm{A}=\mathrm{R}+\mathrm{B}_{\mathrm{a}}
$$

Absorption efficiency (AE) was then calculated using Eq. (5):

$$
\mathrm{AE}=\left(\mathrm{A} / \mathrm{I}_{2}\right) \times 100 \%
$$

Means and standard deviations of percentages were calculated after arc sine transformation of individual values. Statistical differences between experiments were examined by t-tests (Sokal \& Rohlf 1969).

Concentration of cellulose in seston. Water was collected from the Canary Creek marsh on the high spring tide at monthly intervals for 1 yr (March 1985 to February 1986). Triplicate subsamples were measured volumetrically, sieved through a $149 \mu \mathrm{m}$ sieve to remove large particles, and the remaining particulate matter was collected on baked $\left(450^{\circ} \mathrm{C}\right)$ glass-fiber filters (Whatman GF/C). Filters were incubated for $36 \mathrm{~h}$ in a solution of cellulases prepared from Trichoderma viride (Sigma Type V) and Penicillium funiculosum (Sigma Type VII). The antibiotics thimerosal and toluene were added at a concentration of $5 \mathrm{mg} \mathrm{l}^{-1}$ each to prevent microbial activity during incubation (Newell \& Langdon 1986). The release of glucose was measured spectrophotometrically using a hexokinase enzymatic test kit (Sigma $16 \mathrm{UV}$ ) with correction for non-cellulosic contaminants. The amount of digestible cellulose collected on each filter was calculated on the basis of the amount of glucose released from each digest and the concentration of cellulose in the seston determined (Newell \& Langdon 1986).

\section{RESULTS}

\section{Distribution of ${ }^{14} \mathrm{C}$ in the lignocellulosic fraction prepared from Spartina alterniflora}

The mean ${ }^{14} \mathrm{C}$-specific activity of the labeled Spartina alterniflora material was $0.14 \mu \mathrm{Ci} \mathrm{mg}^{-1}$ dry weight. A modified Klason hydrolysis (Benner et al. 1984) indicated that $7.4 \pm 1.6 \%$ (mean $\pm \mathrm{SD}$ ) of the ${ }^{14} \mathrm{C}$-label was distributed in the lignin fraction. The $\left[{ }^{14} \mathrm{C}\right.$ llipid and $\left[{ }^{14} \mathrm{C}\right.$ ]starch fractions accounted for $1.6 \pm 1.5 \%$ (mean $\pm \mathrm{SD}$ ) and $1.7 \pm 1.6 \%$ (mean $\pm \mathrm{SD}$ ) of the ${ }^{14} \mathrm{C}$ of the Lignocellulose, respectively. There was no measurable protein. The remaining portion of the $\left[{ }^{14} \mathrm{C}\right]$ polysaccharide fraction, $89.3 \pm 4.6 \%$ (mean $\pm \mathrm{SD}$ ), was

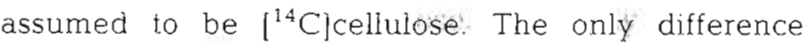
between the $\left({ }^{14} \mathrm{C}\right.$ llignocellulose produced in this study and the material prepared by Newell \& Langdon (1986) was in the $\left[{ }^{14} \mathrm{C}\right]$ starch content, which was significantly (t-test, $p=0.045$ ) lower in this study because of pretreatment with $\alpha$-amylase. 


\section{$\left[{ }^{14} \mathrm{C}\right.$ llignocellulose feeding experiments}

The average filtration rate of Geukensia demissa during the first submergence period was $4.3 \mathrm{l} \mathrm{h}^{-1}$ (g dry tissue weight $[\mathrm{DTW}])^{-1}$ in Expt 1 (January) and 11.01 $\mathrm{h}^{-1}(\mathrm{~g} \mathrm{DTW})^{-1}$ in Expt 2 (March). Ribbed mussels in Expt 2 were more active, clearing more than twice the amount of $\left[{ }^{14} \mathrm{C}\right]$ lignocellulose $\left(7.33 \times 10^{6} \mathrm{dpm} \mathrm{g}\right.$ DTW $\left.^{-1}\right)$ as those in Expt $1\left(3.03 \times 10^{6} \mathrm{dpm} \mathrm{g} \mathrm{DTW}^{-1}\right)$ (Table 1). Ingestion (Eq. 2) of ${ }^{14} \mathrm{C}$ by mussels in Expt 1 was $2.81 \times 10^{6} \mathrm{dpm} \mathrm{g} \mathrm{DTW}^{-1}$ and $6.28 \times 10^{6} \mathrm{dpm} \mathrm{g}$ $\mathrm{DTW}^{-1}$ in Expt 2 (Table 1). Ingestion of ${ }^{14} \mathrm{C}$ by $G$. demissa, when calculated by summation of ${ }^{14} \mathrm{C}$-absorption and ${ }^{14} \mathrm{C}$-defecation (Eq. 3) (Table 1), was not significantly different $(\mathrm{t}$-test, $\mathrm{p}>0.10)$ from ${ }^{14} \mathrm{C}$-ingestion determined by Eq. (2) in both experiments.

Although absolute amounts of ${ }^{14} \mathrm{C}$ measured in each component of the mussel's ${ }^{14} \mathrm{C}$ budget varied greatly among individuals, the proportional relationships between those components varied little. Therefore, the different components of the ribbed mussel's ${ }^{14} \mathrm{C}$ budget were expressed as percentages of the absolute quantity ingested.

Ribbed mussels defecated significantly less $(p=$ 0.025) ${ }^{14} \mathrm{C}$ in Expt 1 than in Expt 2 (Table 1). However, the proportion of ingested ${ }^{14} \mathrm{C}$ that was defecated, approximately $86 \%$, was not significantly different ( $p$ $>0.10$ ) between experiments (Table 1). Production of fecal ${ }^{14} \mathrm{C}$ in each experiment is shown in Fig. 2 as a cumulative percentage loss of the quantity ingested. Defecation patterns were similar in each experiment. Fecal ${ }^{14} \mathrm{C}$ appeared within the first hour from commencement of feeding on the $\left[{ }^{14} \mathrm{C}\right]$ lignocellulose and the rate of defecation increased throughout the first submergence period. Defecation of ${ }^{14} \mathrm{C}$ continued at the onset of the second submergence period; however, the mussels had apparently cleared their guts of ${ }^{14} \mathrm{C}$ by the 18 th hour.

Approximately $4 \%$ of ingested ${ }^{14} \mathrm{C}$ was respired, mainly when the mussels were submerged (Table 1 ). Little respiration of ${ }^{14} \mathrm{CO}_{2}$ occurred when Geukensia demissa were exposed to air in either experiment (Table 1). Absolute respiration of ${ }^{14} \mathrm{C}$ was significantly higher ( $t$-test, $\mathrm{p}=0.020$ ) in the March experiment than in the January experiment (Table 1); however, the proportion of ingested ${ }^{14} \mathrm{C}$ that was respired did not differ significantly ( $t$-test, $p>0.10$ ) between experiments.

Absorption of ${ }^{14} \mathrm{C}$ into body tissue was 3 times greater in the March experiment than in the January experiment (Table 1). However, the proportion of ingested ${ }^{14} \mathrm{C}$

Table 1. Radioactivity (mean dpm $\times 10^{3}$ [g dry tissue weight $]^{-1} \pm$ SD) of each component of the energy budget of Geukensia demissa after being fed $\left[{ }^{14} \mathrm{C}\right.$ lignocellulose in Expts 1 and 2. Values in parentheses represent the mean ( \pm SD) percentage of ingested ${ }^{14} \mathrm{C}\left(\mathrm{I}_{2}\right)$ distributed among each ${ }^{14} \mathrm{C}$-budget component. Differences between experiments were analyzed with t-tests

\begin{tabular}{|c|c|c|c|}
\hline${ }^{14} \mathrm{C}$-budget component & $\begin{array}{c}\text { Expt } 1 \\
\text { Mean } \pm \text { SD }(n=4)\end{array}$ & $\begin{array}{c}\text { Expt } 2 \\
\text { Mean } \pm \operatorname{SD}(n=5)\end{array}$ & $\begin{array}{c}\text { t-test } \\
\text { p-value }\end{array}$ \\
\hline Clearance $(\mathrm{C})$ & $3030 \pm 2060$ & $7330 \pm 1310$ & 0.0081 \\
\hline Pseudofecal deposition (P) & $224 \pm 92$ & $1050 \pm 265$ & $<0.001$ \\
\hline $\begin{array}{l}\text { Ingestion (I) } \\
\qquad \begin{array}{l}\left(I_{1}=C-P\right) \\
\left(I_{2}=F+A\right)\end{array}\end{array}$ & $\begin{array}{c}2810 \pm 2010 \\
2770 \pm 2180 \\
(100 \%)\end{array}$ & $\begin{array}{c}6280 \pm 1350 \\
6150 \pm 1210 \\
(100 \%)\end{array}$ & $\begin{array}{c}0.018 \\
0.019 \\
-\end{array}$ \\
\hline Fecal deposition $(\mathrm{F})$ & $\begin{array}{l}2340 \pm 2010 \\
(86.7 \pm 15.4 \%)\end{array}$ & $\begin{array}{l}5270 \pm 990 \\
(85.8 \pm 3.1 \%)\end{array}$ & $\begin{array}{c}0.025 \\
\text { ns }\end{array}$ \\
\hline $\begin{array}{l}\text { Respiration (R) } \\
\text { Exposed }\left(\mathrm{R}_{\mathrm{e}}\right)\end{array}$ & $\begin{array}{c}8.5 \pm 4.6 \\
(0.37 \pm 0.15 \%)\end{array}$ & $\begin{array}{c}4.1 \pm 2.8 \\
(0.06 \pm 0.03 \%)\end{array}$ & $\begin{array}{c}\text { ns } \\
0.0028\end{array}$ \\
\hline Submerged $\left(R_{s}\right)$ & $\begin{array}{l}100 \pm 66 \\
(4.1 \pm 1.7 \%)\end{array}$ & $\begin{array}{l}213 \pm 47 \\
(3.5 \pm 0.4 \%)\end{array}$ & $\begin{array}{l}0.020 \\
\text { ns }\end{array}$ \\
\hline \multicolumn{4}{|l|}{ Body $(B)$} \\
\hline Unabsorbed gut material $\left(\mathrm{B}_{\mathrm{u}}\right)$ & $\begin{array}{c}2.7 \pm 3.4 \\
(0.08 \pm 0.05 \%)\end{array}$ & $\begin{array}{c}8.6 \pm 8.0 \\
(0.13 \pm 0.11 \%)\end{array}$ & $\begin{array}{l}\text { ns } \\
\text { ns }\end{array}$ \\
\hline Body absorption $\left(\mathrm{B}_{\tilde{a}}\right)$ & $\begin{array}{l}223 \pm 134 \\
(8.7 \pm 1.5 \%)\end{array}$ & $\begin{array}{c}657 \pm 182 \\
(10.5 \pm 1.3 \%)\end{array}$ & $\begin{array}{l}0.0074 \\
\text { ns }\end{array}$ \\
\hline Body incorporation $\left(\mathrm{B}_{1}\right)$ & $\begin{array}{l}\mathrm{nm} \\
\mathrm{nm}\end{array}$ & $\begin{array}{l}277 \pm 104 \\
(4.4 \pm 0.6 \%)\end{array}$ & - \\
\hline $\begin{array}{l}\text { Total absorption } \\
\left(A=R_{e}+R_{s}+B_{a}\right)\end{array}$ & $\begin{array}{c}331 \pm 201 \\
(13.3 \pm 2.5 \%)\end{array}$ & $\begin{array}{c}877 \pm 228 \\
(14.2 \pm 1.6 \%)\end{array}$ & $\begin{array}{c}0.0085 \\
\text { ns }\end{array}$ \\
\hline
\end{tabular}




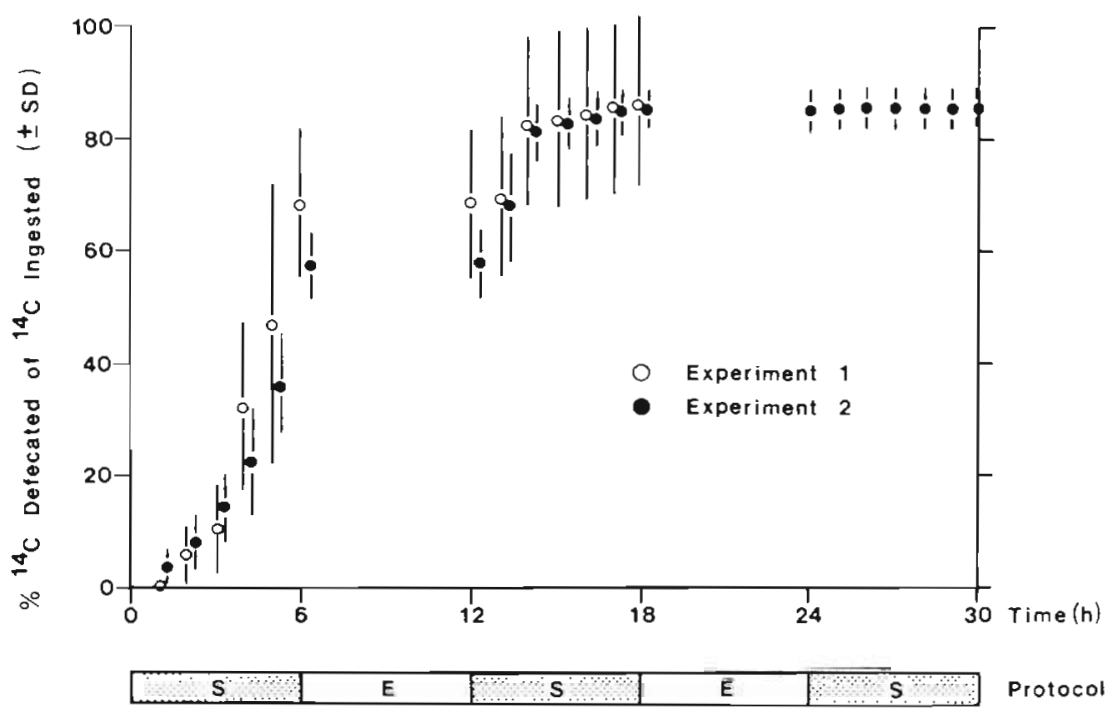

Fig. 2. Geukensia demissa. Average ( $\pm \mathrm{SD}$ ) hourly defecation of ${ }^{14} \mathrm{C}$ in Expts 1 and 2 expressed as a cumulative percentage of ingested ${ }^{14} \mathrm{C}$. Percentages were arc sine transformed before means and standard deviations were calculated that was absorbed into tissue only increased from $8.7 \%$ in Expt 1 (January) to $10.5 \%$ in Expt 2 (March), an insignificant difference (t-test, $p>0.10$ ) (Table 1). Negligible ${ }^{14} \mathrm{C}$ was found undigested in the mussel's gut at the end of each experiment (Table 1). The proportion of absorbed ${ }^{14} \mathrm{C}$ incorporated in the $\left[{ }^{14} \mathrm{C}\right]$ lipid and $\left[{ }^{14} \mathrm{C}\right]$ protein fractions of the mussel's tissue (measured only in the second experiment) totaled $42 \%$, representing $4.4 \%$ of ingested ${ }^{14} \mathrm{C}$ (Table 1 ).

Respiration and absorption of ${ }^{14} \mathrm{C}$ by Geukensia demissa were summed to determine overall absorption of ${ }^{14} \mathrm{C}$ (Table 1 ). The absolute amount absorbed was again significantly higher $(p=0.0085)$ in the second experiment (March); however, proportional absorption values were similar (Table 1).

\section{Seston concentration of cellulose}

Seasonal mean ( $\pm \mathrm{SD}$ ) cellulose concentrations measured in seston collected from the Canary Creek marsh, Delaware, are presented in Table 2 . The concentration of cellulosic material was greatest during winter when water temperatures were lowest (December to April), averaging $127 \mathrm{\mu g} \mathrm{l}^{-1}$ in contrast to a mean of $54 \mathrm{\mu g} \mathrm{l}^{-1}$ from late spring through autumn (May to November). The highest cellulose concentrations occurred in samples collected on 3 Mar 1985, which averaged 165 $\mu \mathrm{g} 1^{-1}$

\section{DISCUSSION}

Geukensia demissa can absorb lignocellulosic carbon derived from Spartina alterniflora with $14 \%$ efficiency and at least $4.4 \%$ of the ingested ration of $\left[{ }^{14} \mathrm{C}\right]$ lignocellulose can be incorporated into tissue (Table 1). Furthermore, in both experiments the proportional utilization of ingested ${ }^{14} \mathrm{C}$ was consistent among individual mussels, despite highly variable absolute amounts ingested by individuals (Table 1)

The average filtration rates of Geukensia demissa were $4.3 \mathrm{l} \mathrm{h}^{-1}$ (g dry tissue weight [DTW]) ${ }^{-1}$ in Expt 1 and $11.0 \mathrm{l} \mathrm{h}^{-1} \mathrm{~g} \mathrm{DTW}^{-1}$ in Expt 2, which are similar to rates reported by other workers for ribbed mussels of similar size. Jordan \& Valiela (1982) observed a mean summer filtration rate of $3.5 \mathrm{l} \mathrm{h}^{-1} \mathrm{~g} \mathrm{DTW}^{-1}$ and Kuenzler $(1961 \mathrm{~b})$ documented an average rate of $6.81 \mathrm{~h}^{-1} \mathrm{~g}$ $\mathrm{DTW}^{-1}$ at temperatures from 10 to $20^{\circ} \mathrm{C}$. The filtration rate and resulting clearance of $\left[{ }^{14} \mathrm{C}\right]$ lignocellulose by mussels in the second experiment was significantly greater than that of mussels in Expt 1 (Table 1), perhaps because the marsh water used in the January experiment differed in seston concentration from that of the March experiment. Alternatively, the physiological condition of the mussels may have changed from January to March, resulting in different rates of activity

Table 2. Seasonal mean ( \pm SD) cellulose concentrations in seston collected from the Canary Creek study site at high spring tide over $1 \mathrm{yr}$

\begin{tabular}{|lc|}
\hline Season (collection dates) & $\begin{array}{c}\text { Cellulose concentration } \\
\text { Mean } \pm \mathrm{SD}(\mathrm{n}=6) \\
\left(\mu \mathrm{g} \mathrm{l^{-1 }}\right)\end{array}$ \\
\hline Winter (27 Dec, 4 Feb, 3 Mar) & $122 \pm 42$ \\
Spring (7 Apr, 5 May, 3 Jun) & $57 \pm 75$ \\
Summer (4 Jul, 2 Aug, 29 Aug) & $66 \pm 28$ \\
Fall (1 Oct, 29 Oct, 26 Nov) & $68 \pm 3$ \\
Annual mean ( $\pm \mathrm{SD}, \mathrm{n}=12)$ & $78 \pm 47$ \\
\hline
\end{tabular}


between the 2 groups (Bayne \& Newell 1983). Absolute ${ }^{14} \mathrm{C}$-activities of the major components of the ${ }^{14} \mathrm{C}$ budget were higher in the second experiment due to increased clearance of $\left[{ }^{14} \mathrm{C}\right]$ lignocellulose (Table 1).

Rejection of ${ }^{14} \mathrm{C}$ in pseudofeces accounted for less than $15 \%$ of ${ }^{14} \mathrm{C}$ cleared from suspension. Agreement between both indirect calculations of ${ }^{14} \mathrm{C}$-ingestion (Table 1) supports the assumption that negligible ${ }^{14} \mathrm{C}$ was lost in non-fecal excretion. Defecation of ${ }^{14} \mathrm{C}$ accounted for $86 \%$ of ${ }^{14} \mathrm{C}$ ingested (Table 1). The hourly pattern of ${ }^{14} \mathrm{C}$ production in feces was characterized by rapid deposition of unabsorbed material (Fig. 2). Negligible ${ }^{14} \mathrm{C}$ was defecated after the third hour of the second period of submergence (9th hour of submergence) suggesting a short gut residence time. A similar time-course of defecation was reported by Kuenzler (1961b) who fed continuously submerged Geukensia demissa ${ }^{32} \mathrm{P}$-labeled diatoms. Only $8 \%$ of ingested ${ }^{32} \mathrm{P}$ remained in the gut of the mussels $12 \mathrm{~h}$ after feeding (Kuenzler 1961b).

Respiration of ${ }^{14} \mathrm{C}$ by Geukensia demissa represented only $30 \%$ of ${ }^{14} \mathrm{C}$-absorption (Table 1 ). Metabolic costs typically demand $70 \%$ of carbon assimilated by ribbed mussels (Kuenzler 1961a). The respiration rate of $G$. demissa in this study may have been depressed because of a change in food availability or because the physiological condition of the mussels may have differed from those of animals studied elsewhere (Bayne \& Newell 1983). The absence of ${ }^{14} \mathrm{C}$-respiration while mussels were exposed to air (Table 1) suggests that ${ }^{14} \mathrm{C}$-labeled products of cellulose digestion may not have been utilized for aerobic respiration during the limited duration of these experiments. It is unlikely that the mussels were metabolizing anaerobically, since $G$. demissa typically respire aerobically while exposed to air (Widdows et al. 1979, Nicchitta \& Ellington 1983).

Although ${ }^{14} \mathrm{C}$-absorption efficiencies were similar between experiments, the proportion of absorbed ${ }^{14} \mathrm{C}$ used for respiration and assimilated into body tissues differed significantly between experiments (Table 1). Mussels were possibly directing more energy into gonadal tissue during the March experiment when gonad development naturally occurs (Lind 1975).

Reports of high absorption efficiencies for bivalves fed on phytoplankton are numerous (Winter 1978, Bayne \& Newell 1983). In contrast, little information is available concerning the quantitative ability of bivalves to assimilate refractory compounds. Most studies have either evaluated the growth of bivalves fed detritus (Kirby-Smith 1976, Pennock 1981, Williams 1981), estimated detrital digestibility in bivalves using in vitro gut enzyme assays (Crosby \& Reid 1971, Lucas \& Newell 1984), or estimated the origin of dietary material from stable isotope ratios of bivalve tissues
(Haines \& Montague 1979, Hughes \& Sherr 1983, Peterson et al. 1985, 1986). Assimilation of vascular marsh plant detritus by bivalves has only recently been quantified (Newell \& Langdon 1986, Crosby 1987), and it remains unclear whether utilization occurs directly or indirectly via heterotrophic microorganisms. Stuart et al. (1982) reported assimilation efficiencies of up to $50 \%$ for Aulacomya ater fed on detritus formed from kelp; however, structural materials of seaweed are less refractory than those of salt marsh plants, such as Spartina alterniflora (Findlay \& Tenore 1982).

Absorption efficiency of detritus by the oyster Crassostrea virginica was investigated by Newell \& Langdon (1986), using a $\left[{ }^{14} \mathrm{C}\right]$ lignocellulose preparation similar to that used in this study. As only $1.3 \%$ of the ${ }^{14} \mathrm{C}$ was absorbed over a $24 \mathrm{~h}$ incubation period, Newell \& Langdon (1986) concluded that lignocellulose was unimportant as a source of carbon. The observation that Geukensia demissa can absorb $14 \%$ of a $\left[{ }^{14} \mathrm{C}\right]$ lignocellulose diet quantitatively supports previous suggestions that the ribbed mussel has a greater ability to utilize marsh grass detritus than the oyster (Haines \& Montague 1979, Hughes \& Sherr 1983, Peterson et al. 1986).

The contribution of cellulosic carbon to the energy requirements of Geukensia demissa during summer can be estimated by considering the mussel's ability to ingest and absorb $\left[{ }^{14} \mathrm{C}\right]$ lignocellulose, the mussel's summer carbon requirement, and summer concentrations of seston cellulose. Present data can validly be used in this estimation, hecause summer seston temperatures most closely approximate the laboratory temperature of this study $\left(21^{\circ} \mathrm{C}\right)$. Widdows et al. (1979) reported submerged and exposed respiration rates for G. demissa to be $0.41 \mathrm{ml} \mathrm{h}^{-1} \mathrm{~g} \mathrm{DTW}^{-1}$ and $0.23 \mathrm{ml} \mathrm{h}^{-1} \mathrm{~g}$ $\mathrm{DTW}^{-1}$, respectively, at $20^{\circ} \mathrm{C}$. Assuming that Canary Creek mussels are exposed to air $50 \%$ of the time, their overall respiration rate would be $0.32 \mathrm{ml} \mathrm{h}^{-1} \mathrm{~g} \mathrm{DTW}^{-1}$, which is equivalent to $0.17 \mathrm{mg} \mathrm{Ch}^{-1} \mathrm{~g} \mathrm{DTW}^{-1}$. Assuming that $30 \%$ of assimilated energy is utilized for growth (Kuenzler 1961a), the total carbon requirement of $G$. demissa for growth and respiration would be 0.24 $\mathrm{mg} \mathrm{Ch}^{-1} \mathrm{~g} \mathrm{DTW}^{-1}$. It is assumed that a mean carbon demand of $0.24 \mathrm{mg} \mathrm{C} \mathrm{h}^{-1} \mathrm{~g} \mathrm{DTW}^{-1}$ and a mean (Expt 1 and $2, \mathrm{n}=9$ ) filtration rate of $7.81 \mathrm{~h}^{-1} \mathrm{~g} \mathrm{DTW}^{-1}$ for mussels are representative of Canary Creek mussels during summer temperatures.

The summer (1985) mean concentration of cellulose in seston from the Canary Creek marsh was $66 \mu \mathrm{g}^{-1}$ (Table 2). Ribbed mussels filtering at a rate of $7.8 \mathrm{l} \mathrm{h}^{-1}$ $\mathrm{g} \mathrm{DTW}^{-1}$ could, therefore, clear $0.51 \mathrm{mg} \mathrm{h}^{-1} \mathrm{~g} \mathrm{DTW}^{-1}$ while submerged, which is equivalent to $0.26 \mathrm{mg} \mathrm{h}^{-1} \mathrm{~g}$ $\mathrm{DTW}^{-1}$ per tidal cycle. With a $14 \%$ absorption efficiency for lignocellulosic carbon (Table 1), Geukensia demissa could absorb cellulosic carbon at a rate of 
$0.036 \mathrm{mg} \mathrm{Ch} \mathrm{h}^{-1} \mathrm{~g} \mathrm{DTW}^{-1}$. Absorption of seston cellulose could therefore satisfy $15 \%$ of the ribbed mussel's summer total carbon demand. Refractory cellulosic carbon may be a more important resource for ribbed mussels at other times of the year, however, when metabolic energy demands are reduced (Kuenzler 1961a, Hilbish 1987) and when concentrations of seston cellulose are higher (Table 2).

Acknowledgements. We thank Ms Linda Franklin for determination of cellulose concentrations from seston samples. This research was funded by a grant (\# OCE-8000264) from the Biological Oceanography division of the National Science Foundation to Drs R. I. E. Newell, C. J Langdon, and H. Ducklow.

\section{LITERATURE CITED}

Bayne, B. L. (1976). Marine mussels: their ecology and physiology. Cambridge Univ. Press, New York, p. 227-232

Bayne, B. L., Newell, R. C. (1983). Physiological energetics of marine molluscs. In: Saleuddin, A. S. M., Wilbur, K. M. (eds.) The Mollusca, Vol. 4, Physiology, Part 1. Academic Press, New York, p. 407-515

Benner, R., Maccubbin, A. E., Hodson, R. E. (1984). Preparation, characterization and microbial degradation of specifically radiolabeled $\left[{ }^{14} \mathrm{C}\right]$ lignocelluloses from marine and freshwater macrophytes. Appl. environ. Microbiol. 47 381-389

Crosby, M. P. (1987). Utilization of detrital complexes by the oyster Crassostrea virginica (Gmelin). Ph. D. dissertation, University of Maryland

Crosby, N. D., Reid, R. G. (1971). Relationships between food, physiology and cellulose digestion in the Bivalvia. Can. J. Zool. 49: 617-622

Findlay, S., Tenore, K. (1982). Nitrogen source for a detritivore: detritus substrate versus associated microbes. Science 218: 371-373

Gillmor, R. B. (1982). Assessment of intertidal growth and capacity adaptations in suspension-feeding bivalves. Mar. Biol. 68: 277-286

Haines, E. B., Hanson, R. B. (1979). Experimental degradation of detritus made from the salt marsh plants Spartina alterniflora, Salicornia virginica, and Juncus roemerianus. J. exp. mar. Biol. Ecol. 40:27-40

Haines, E. B., Montague, C. L. (1979). Food sources of estuarine invertebrates analyzed using ${ }^{13} \mathrm{C} /{ }^{14} \mathrm{C}$ ratios. Ecology 60: 48-56

Heinle, D. R., Flemer, D. A. (1976). Flows of materials between poorly flooded tidal marshes and an estuary. Mar. Biol. 35: $359-373$

Hilbish, T J. (1987). Response of aquatic and aerial metabolic rates in the ribbed mussel Geukensia demissa (Dillwyn) to acute and prolonged changes in temperature. J. exp. mar. Biol. Ecol. 105: 207-218

Hildreth, D. I., Crisp, D. J. (1976). A corrected formula for calculations of filtration rate of bivalve molluscs in an experimental flowing system. J. mar. biol. Ass. U. K. 56: $111-120$

Holland, D. L., Gabbott, P. A. (1971). A micro-analytical scheme for the determination of protein, carbohydrate, lipid and RNA levels in marine invertebrate larvae. J. mar biol. Ass. U. K. 51: 659-668
Hughes, E. H., Sherr, E. B. (1983). Subtidal food webs in a Georgia estuary: $d^{13} \mathrm{C}$ analysis. J. exp. mar. Biol. Ecol. 67 : $227-242$

Jordan, T E., Valiela, I. (1982). A nitrogen budget of the ribbed mussel. Geukensia demissa, and its significance in nitrogen flow in a New England salt marsh. Limnol. Oceanogr. 27: 75-90

Kirby-Smith, W. W. (1976). The detritus problem and the feeding and digestion of estuarine organisms. In: Wiley, M. (ed.) Estuarine processes, Vol. I. Academic Press, New York, p. $469-479$

Kreeger, D. A. (1986). Utilization of refractory cellulosic material derived from Spartina alterniflora (Loisel.) by the ribbed mussel Geukensia demissa (Dillwyn). Master's thesis, University of Delaware

Kuenzler, E. J. (1961a). Structure and energy flow in a mussel population in a Georgia salt marsh. Limnol. Oceanogr. 6 : 191-204

Kuenzler, E. J. (1961b). Phosphorus budget of a mussel population. Limnol. Oceanogr 6: 400-415

Lind, H. F. (1975). The effect of temperature on gametogenic development in two bivalve species, Mya arenaria and Modiolus demissus. Master's thesis, University of Delaware

Lucas, M. I., Newell, R. C. (1984). Utilization of saltmarsh grass detritus by two estuarine bivalves: carbohydrase activity of crystalline style enzymes of the oyster Crassostrea virginica (Gmelin) and the mussel Geukensia demissa (Dillwyn). Mar. Biol. Lett. 5: 275-290

Maccubbin, A. E., Hodson, R. E. (1980). Mineralization of detrital lignocelluloses by salt marsh sediment microflora. Appl. environ. Microbiol. 40: 735-740

Marinucci, A. C. (1982). Trophic importance of Spartina alterniflora production and decomposition to the marsh ecosystem. Biol. Conserv. 22: 35-58

McIntire, G. L., Dunstan, W. M. (1976). Non-structural carbohydrates in Spartina alterniflora Loisel. Botanica mar. 19: 93-96

Morton, B. (1983). Feeding and digestion in Bivalvia. In: Saleuddin, A. S. M., Wilbur, K. M. (eds.) The Mollusca, Vol. 5, Physiology, Part 2. Academic Press, New York, p. $65-147$

Newell, R. I. E., Langdon, C. J. (1986). Digestion and absorption of refractory carbon from the plant Spartina alterniflora by the oyster Crassostrea virginica. Mar. Ecol. Prog. Ser. 34: 105-1.15

Nicchitta, C. V., Ellington, W R. (1983). Energy metabolism during air exposure and recovery in the high intertidal bivalve mollusc Geukensia demissa granosissima and the subtidal bivalve mollusc Modiolus squamosus. Biol. Bull. mar. biol. Lab., Woods Hole 165: 708-722

Odum, E. P., de la Cruz, A. A. (1967). Particulate detritus in a Georgia salt marsh-estuanne ecosystem. In: Lauff, G. H. (ed.) Estuaries. AAAS Publ. 83, Washington, D. C., p. $383-388$

Pennock, J. H. (1981). The role of Spartina alterniflora detritus in the nutrition of the American oyster, Crassostrea virginica. Master's thesis, University of Delaware

Peterson, B. J., Howarth, R. W., Garritt, R. H. (1985). Multiple stable isotopes used to trace the flow of organic matter in estuarine food webs. Science 227. 1361-1363

Peterson, B. J., Howarth, R. W., Garritt, R. H. (1986). Sulfur and carbon isotopes as tracers of salt-marsh organic matter flow. Ecology 67: 865-874

Pickral, J. C., Odum, W E. (1976). Benthic detritus in a saltmarsh tidal creek In: Wiley, $M$. (ed.) Estuarine processes, Vol II. Academic Press, New York, p. 280-292 
Pomeroy, L. R., Wiegert, R. G. (1981). The ecology of a salt marsh. Springer-Verlag, New York

Smith, K. K., Good, R. E., Good, N. F. (1979). Production dynamics for above and below ground components of a New Jersey Spartina alterniflora tidal marsh. Estuar. coast. Shelf Sci. 9: 189-201

Sokal, R. R., Rohlf, F. J. (1969). Biometry. W. H. Freeman, San Francisco

Squiers, E. R., Good, R. E. (1974). Seasonal changes in the productivity, caloric content and chemical composition of a population of salt marsh cordgrass (Spartina alterniflora) Chesapeake Sci. 15: 63-71

Stuart, V., Field, J. G., Newell, R. C. (1982), Evidence for absorption of kelp detritus by the ribbed mussel Aulacomya ater using a new ${ }^{51} \mathrm{Cr}$-labelled microsphere technique. Mar. Ecol. Prog. Ser. 9: 263-271

Teal, J. M. (1962). Energy flow in the salt marsh ecosystem of Georgia. Ecology 43: 614-624
Valiela, I., Teal, J. M., Allen, S. D., Van Etten, R., Goehringer, D., Volkmann, S. (1985). Decomposition in salt marsh ecosystems: the phases and major factors affecting disappearance of above-ground organic matter. J. exp. mar. Biol. Ecol. 89: 29-54

Widdows, J., Bayne, B. L., Livingstone, D. R., Newell, R. I. E., Donkin, P. (1979). Physiological and biochemical responses of bivalve molluscs to exposure to air. Comp. Biochem. Physiol. 62 A: 301-308

Williams, P. (1981). Detritus utilization by Mytilus edulis. Estuar. coast. Shelf Sci. 12: 739-746

Wilson, J. O., Buchsbaum, R., Valiela, I., Swain, T. (1986). Decomposition in salt marsh ecosystems: phenolic dynamics during decay of litter of Spartina alterniflora. Mar. Ecol. Prog. Ser 29: 177-187

Winter, J. E. (1978). A review of the knowledge of suspensionfeeding in lamellibranchiate bivalves, with special reference to artificial aquaculture systems. Aquaculture 13: 1-33

This article was submitted to the editor; it was accepted for printing on November 19, 1987 